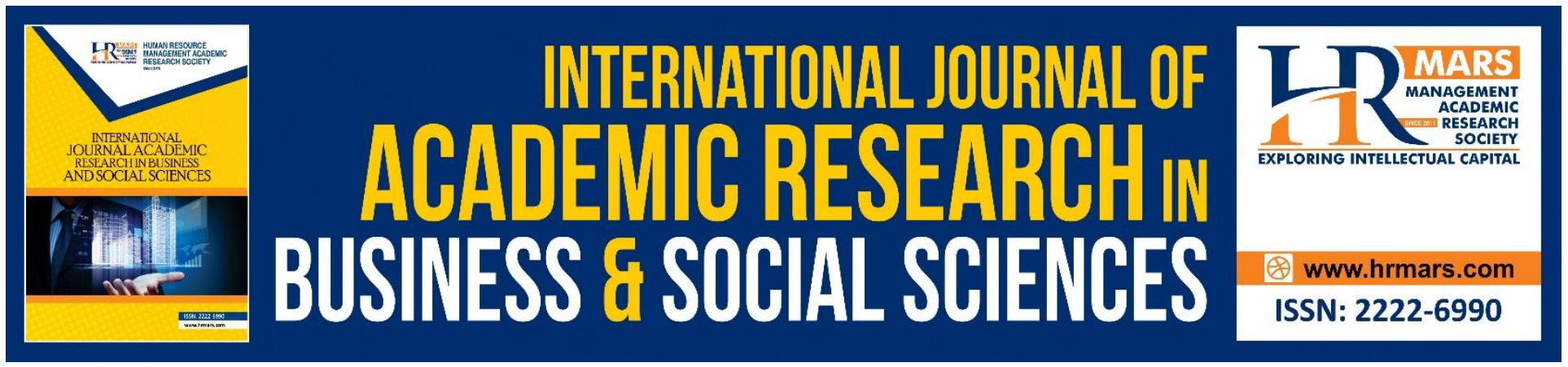

\title{
Malaysian Women Entrepreneurs: Some Emerging Issues and Challenges of Entering Global Market
}

Filzah Md Isa, Mathivannan Jaganathan, Muhd Afiq Syazwan Ahmdon, Hairunnisa Mohamad Ibrahim

To Link this Article: http://dx.doi.org/10.6007/IJARBSS/v8-i12/5261

DOI: $10.6007 /$ IJARBSS/v8-i12/5261

Received: 18 Oct 2018, Revised: 24 Dec 2018, Accepted: 06 Jan 2019

Published Online: 11 Jan 2019

In-Text Citation: (Isa, Jaganathan, Ahmdon, \& Ibrahim, 2018)

To Cite this Article: Isa, F. M., Jaganathan, M., Ahmdon, M. A. S., \& Ibrahim, H. M. (2018). Malaysian Women Entrepreneurs: Some Emerging Issues and Challenges of Entering Global Market. International Journal of Academic Research in Business and Social Sciences, 8(12), 1596-1605.

Copyright: (c) 2018 The Author(s)

Published by Human Resource Management Academic Research Society (www.hrmars.com)

This article is published under the Creative Commons Attribution (CC BY 4.0) license. Anyone may reproduce, distribute, translate and create derivative works of this article (for both commercial and non-commercial purposes), subject to full attribution to the original publication and authors. The full terms of this license may be seen

at: http://creativecommons.org/licences/by/4.0/legalcode

Vol. 8, No. 12, 2018, Pg. 1596 - 1605

http://hrmars.com/index.php/pages/detail/IJARBSS

JOURNAL HOMEPAGE

Full Terms \& Conditions of access and use can be found at http://hrmars.com/index.php/pages/detail/publication-ethics 


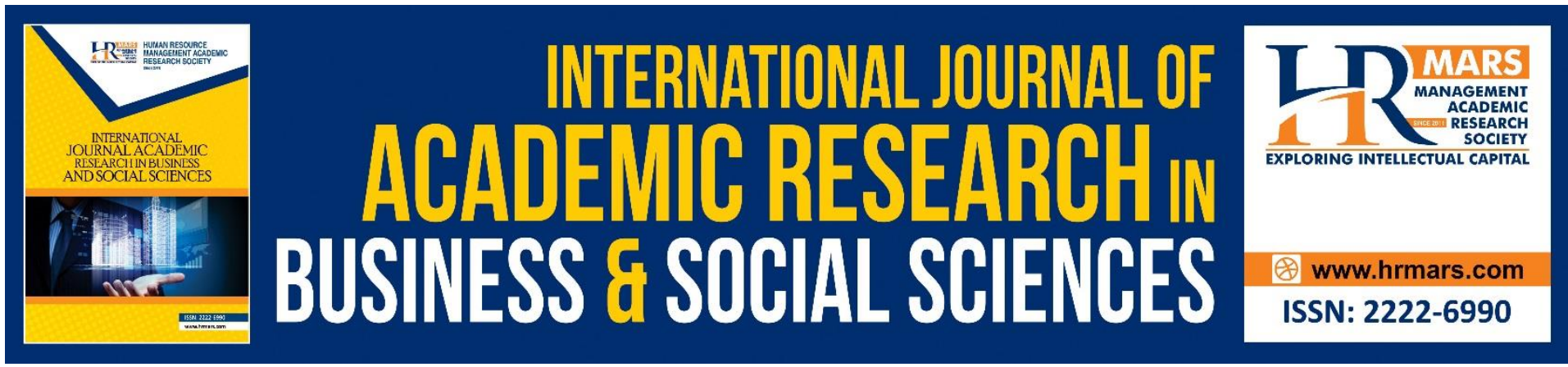

\title{
Malaysian Women Entrepreneurs: Some Emerging Issues and Challenges of Entering Global Market
}

\author{
Filzah Md Isa \\ Taylor's University, Malaysia \\ Mathivannan Jaganathan \\ Universiti Utara Malaysia, Malaysia \\ Muhd Afiq Syazwan Ahmdon \\ Taylor's University, Malaysia \\ Hairunnisa Mohamad Ibrahim \\ Taylor's University, Malaysia
}

\begin{abstract}
The involvement of women entrepreneur in Malaysia has increased in the past few decades and significantly contributed to Malaysian economy development. However, some perennial issues and challenges constantly impeding women entrepreneurs from dominating entrepreneurial activities. Therefore, this study was conducted to investigate issues and challenges related to women entrepreneurs especially when entering the global market. Subsequently, the objectives of this study are to gather and examine pertinent information on women entrepreneurs and how successful women entrepreneurs in Malaysia prepared and handled issues and challenges arise during their international market penetration. For the purpose of capturing the required data, personal face-to-face interview with women entrepreneurs were conducted by using purposive sampling approach. Specifically, 10 women entrepreneurs from the northern region of Malaysia were involved in this study. The findings of this study provide some insights on women issues and challenges specifically related to individual, organizational and environmental factors. The results also will be helpful to the individual (spouse and family) and government to give more support to the women entrepreneurs in terms of moral, financial and non-financial.
\end{abstract}

Keywords: Women Entrepreneur, Issues and Challenges, Global market • Malaysia

\section{INTRODUCTION}

In light of recent events in the Malaysian entrepreneurial activities, it is becoming extremely difficult to ignore the existence of Malaysian women entrepreneurs that involved in the various business sectors since the last decades. Over the years, we have been observing an emerging trend of more Malaysian women entrepreneurs choosing to start their own business 
such as real estate, food and beverage, fashion apparel, trading, import and so on (Basha, Pranav, Rao, Madhavi, \& Sudha, 2013; Rozita, Rozita, Nur Syakiran Akmal, \& Zalinah, 2015) Recently, one of the mainstream newspapers also stated that one in five companies operated by women entrepreneurs compared to last few decades based on the data provided by the Statistics Department of Malaysia (Babulal, 2017). Moreover, 20.6\% percentage of total SMEs in Malaysia wholly own by women entrepreneurs ("SMEs are backbone of the economy," n.d.). It can be clearly seen through dramatic changes in Malaysian Economy rose to 37\% in 2017.

However, support for SME growth and competitiveness has become mandatory due to the 1997-1998 Malaysia financial crisis and also due to some other micro-issues such as training on technology, marketing and access to finance. Moreover, government grants and funds such as TEKUN, SME Corp, Amanah Ikthiar Malaysia (AIM) and Ministry of Women, Family and Community Development (MWFCD) were introduced to encourage Malaysian Women to become entrepreneurs. For example, TEKUN increased the fund up to RM100 million, MARA prepared RM50 million through Dana Nita, and SME Bank through Women Entrepreneurs Program (WEP) allocated RM200 million.

Although there are many past reports, academic and non-academic literature gave the plausible impression on the number of women business formation, yet the number of successful women entrepreneurs is far minimal compared to men, and men entrepreneurs still dominating most of renown entrepreneurial activities (Alam, Senik, \& Jani, 2012; Ariffin, Mohamed, Baqutayan, \& Mahdzir, 2017). In general, entrepreneurs plays a vibrant role in economic development of their families and countries (Ali et al., 2017); but relatively women entrepreneurs ' business performance is still very low (Cooper, Gimeno-Gascon, \& Woo, 1994; Ekpe, Razak, \& Mat, 2013; Hassan, Ramli, \& Mat Desa, 2014; Marlow \& Mcadam, 2013; Yassin, Ali, Abdel, \& Ali, 2014). Earlier studies also clearly indicated inconsistent findings on the performance of women entrepreneurs. Some of the studies found that man's business performance is higher than women whereas women entrepreneurs have low-slung business performance compared to male. Thus, the majority of their business remains small and marginal as well as low in growth and competitiveness

Therefore, this in-depth case-study critically reviewed some developmental issues and critical success factors by investigating issues and challenges in entering global market particularly those who involved in Small and Medium Enterprises (SMEs) in Malaysia, a country which always considered as one of the fastest developing economies in South East Asia region.

\section{WOMEN ENTREPRENEURSHIP, ISSUES, AND CHALLENGES}

The world has experienced unprecedented growth of women entrepreneurship over the past few decades where approximately $25 \%$ of businesses operated by women entrepreneurs. For instance, United States of America that produced most successful global entrepreneurs also makes up 39\% of women entrepreneur which is only 29\% in 2007 (Carlos M. Gutierrez, 2017). Despite the tremendous changes in women entrepreneur's growth but some unanticipated challenges still persist regardless of country. Similar to other countries in the world, women entrepreneurs in Malaysia also face various challenges in running their business operation. Beside gender issue, some other challenges are trailing their success paths such as funding and family support (Cabrera \& Mauricio, 2017; Ekpe et al., 2013) . On the other hand, apart from being homemakers, the women in Malaysia have essential roles to play in the economy of Malaysia (Mohd. Nordin et al., 2011; Pandey, 2013)

Generally, women entrepreneurs associated with increased issues and challenges during the process of initiating and running a business. For instance, cultural values have a limit to the women entrepreneurs (C Mordi, Simpson, Singh, \& Okafor, 2010). In reality, the traditional role of women is still taking place in most of the Asian countries especially Malaysia. In an old fashion 
society, women perceived as an individual who work at home taking care children and carrying out household obligations as their core duty. In addition, women entrepreneurs are expected to control their home chores while managing company definitely will cause conflicts and lead to inappropriate business directions (Kian, Mi, \& Chun, 2016). The dilemma for women entrepreneurs has become a challenge and issue while having other responsibility. There is a strong possibility that Malaysian women entrepreneurs give less attention to their business due to their concern on family matters even they have an opportunity and support from government agencies to conduct the business (Orser, Elliott, \& Leck, 2011).

Another significant issue in women entrepreneurship is gender inequality. In terms of loans and funds accessibility, women face challenges accessing compared to a male (Rozita et al., 2015). Apart from that, women entrepreneurs may be relatively less well represented among entrepreneurs but better represented in growth-oriented forms of entrepreneurship. Although both male and women are similarly motivated by opportunity than necessity as a primary set up business ventures, the failure rate amongst women is higher compared to male.

A few challenges were identified and found that several women entrepreneurs are still facing numerous difficulties to start the business and during the development phase of their enterprises. Previous study also reported Malaysian women entrepreneurs faced enormous challenges from the local and international market during their business start-up, in domestic operation, and in international business operation (Hodges et al., 2015; Ilhaamie, 2014; Mahmood \& Hanafi, 2013). However, these challenges did not impede them from being successful in their business activities. Apparently, women seem to be successful in both local and international markets compared to their male counterparts since they premeditated and executed effective business strategies to supply their target markets.

Furthermore, due to a lot of duties and responsibilities, women entrepreneurs have less desire to participate in many activities and tend to keep their business small to avoid unprecedented conflicts. Both female and male entrepreneurs face relatively different business constraints throughout the region, but these constraints possibly impede the women owned enterprises more severe. Some interesting findings from past studies stated that successful women in Canada or the USA usually related to those women who are unmarried and childless, unlike Argentina and Mexico that involved married women with children (Wang, 2018).

Furthermore, access to financial resources also a major issue and challenge for women entrepreneurs especially in the developing countries. In fact, women feel it's an ultimate challenge to raise fund and also fail to secure loan due to required collateral. This phenomenon possibly related to culture and norms in the certain countries which restrict women to inherit or own assets and social position (Dhillon, 2017; Watson, 2001). Previous studies stated that women owned enterprises relatively smaller size, less profits and survival of the business is shorter than male owned businesses (Cabrera \& Mauricio, 2017; Mahmood \& Hanafi, 2013; Chima Mordi, Simpson, Singh, \& Okafor, 2010; Pandey, 2013) . 


\section{METHODOLOGY}

For the purpose of this study, case study method was employed since it provides first-hand information from participants. Case study gives relatively high accuracy to the researcher to understand phenomenon rather than measure and evaluate by using quantitative method (Yin, 2002). The sample settings for the case study were derived from the Ministry of International Trade and Industry (MITI's) successful entrepreneurs list, Penang Malay Chamber of Commerce (Dewan Perniagaan Pulau Pinang) and Majlis Amanah Rakyat Pulau Pinang (MARA). Purposive sampling was used to approach women entrepreneurs in this study. The study focused on women entrepreneurs who were operating at the domestic and international market.

\section{Table 1.0 Summary of Personal and Business Background}

COMPANY NAME

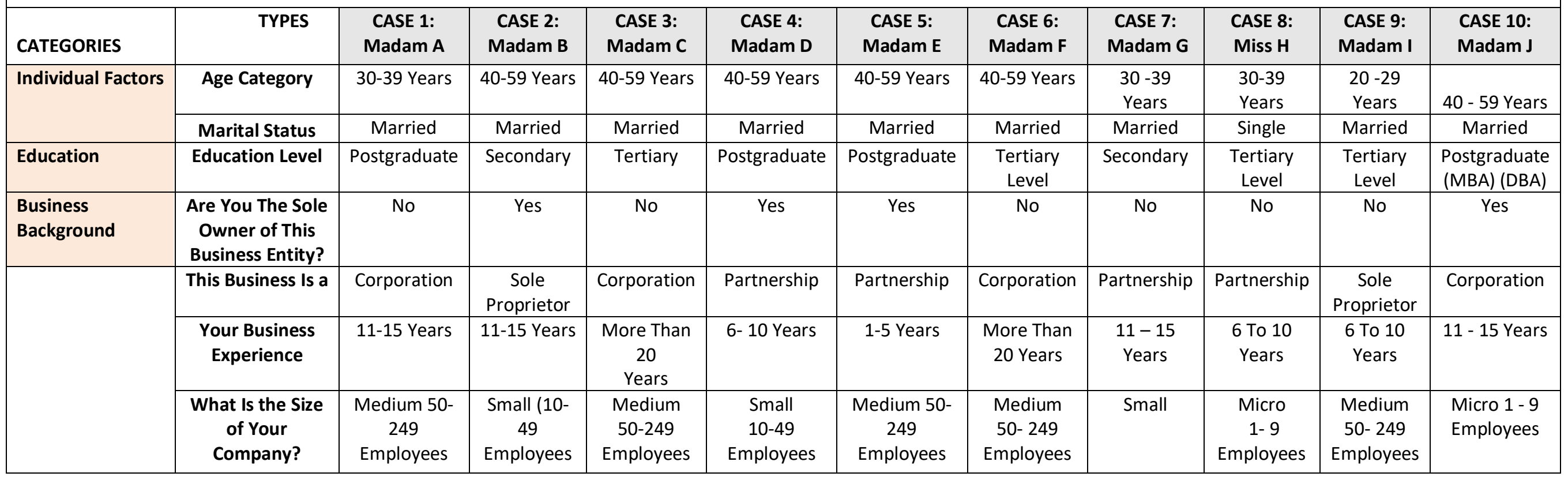


INTERNATIONAL JOURNAL OF ACADEMIC RESEARCH IN BUSINESS AND SOCIAL SCIENCES Vol. 8, No. 12, Dec, 2018, E-ISSN: 2222-6990 @ 2018 HRMARS

The researcher used personal face-to-face interview, confirmation via telephone and secondary information such as documents, company profiles, and other related material describing the company's achievements or milestones. The structured interviews were done by the interviewer who asked probing questions to the interviewee and then, through reflective prompts and active listening, keeps them talking and then ask further specific questions. The structured interviews were focused on questions explanation on how the women entrepreneurs penetrate international markets.

\section{RESULTS AND DISCUSSION}

Analysis of the cases was carried out by considering frequencies and the magnitude of the research findings. A cross-case analysis was also conducted to emphasize the uniqueness of each case. The synopsis of each case was also presented to provide insightful information regarding the women entrepreneur's business operations. Based on the Table 1.0, most of the participants were above 30 years old except case 9 . This is very common in the business due to most of the businesses were started by entrepreneurs after 5 years of experiences upon completion of their studies.

Interestingly, most of the interviewed entrepreneurs were married except case 8. As expected, most of the business owners are not the sole owner of the firm except Case 2 and Case 10. Referring to the question "what are the biggest problems you encountered in the international market? How did you overcome those problems?" (Case 2) implied that she does not require an international business partner. However, the Case 7, 8, 9 and 10 provide a different answer regarding this issue. Two of them do not require an international business partner (Case 7 and 10) whereas the other two (Case 8 and 9) stated that they need an international partner in foreign countries who are not a family member.

Table 1.1 Issues and Challenges Faced by Women Entrepreneurs

\begin{tabular}{|c|c|c|}
\hline NO & CASE & $\begin{array}{l}\text { What were the biggest problems you encountered in the international market? How } \\
\text { did you overcome those problems? }\end{array}$ \\
\hline 1 & Case 1 & China market only accepts big deal business. \\
\hline 2 & Case 2 & Culture of local market \\
\hline 3 & Case 3 & Different procedures and law restriction. \\
\hline 4 & Case 4 & Different ways of dealing the business, either CIF or FOB. \\
\hline 5 & Case 5 & Different ways of dealing the business, either CIF or FOB, different regulations. \\
\hline 6 & Case 6 & $\begin{array}{l}\text { Fluctuation of exchange rates, have to bear the penalty if the product is damaged and } \\
\text { have to comply the green policy and requirement stated by customers. }\end{array}$ \\
\hline 7 & Case 7 & Finding support from the market like customer,distributor, supplier and also finance. \\
\hline 8 & Case 8 & Cash flow, paying back of interest and reinvestment \\
\hline 9 & Case 9 & One man show with a small office \\
\hline 10 & $\begin{array}{l}\text { Case } \\
10\end{array}$ & Lack of referrals. \\
\hline
\end{tabular}

In relation to question " How did you overcome those problems??" Case 1 stated that she believes that a backup plan will solve the issues. However, Case 2 responded that updating the problems through meetings and being closer and not strict with the employees will help her control 
the business problems from becoming more serious. On the other hand, Case 3 mentioned that she is willing to take the risk whenever problems become serious. Likewise, Case 4 used various strategies to control business challenges. In contrast, Case 5 focusing on strategies in rolling the capital while Case 6 controls the business problem by monitoring the rejection rate using a suitable system. In relation to the similar question regarding controlling the business problem, the Case 7-10 provided different responses. For instance, Case 7 mentioned that she will focus more on discussion with staff and try her best to find out the root of the problem with them while Case 8 stated that she would take charge of the problem and focus more on increasing promotion. Case 9 controls the problems via communication, monitoring and taking proper action to control it. In contrast, Case 10 responded that she will focus on her strength and tries to move away from the low-end segments.

To be able to succeed in the local and international market, every entrepreneur has to properly control their problems from becoming serious; there are many strategies to do so. For example, participant 2 (case 2 ) stated:

"I will conduct meeting with my staffs, I cannot be too strict, and I have to use proper strategies to make them listen to my decision."

Case 8 said that:

"I will take charge of the problem, increase efforts in promotion, advertise in the internet where the customers are found in the Facebook."

Case 10 mentioned that:

"I will focus on my strength and move away from the low-end segments."

To be a successful international business player, women entrepreneurs need to possess certain entrepreneurial traits like persistence, risk-taking, passionate and confidence that strongly relate to good moral values. Inherently, every women entrepreneur in Malaysia can possibly be a successful entrepreneur if she maintains and preserves the individual factors as revealed in the study.

As suggested by women entrepreneurs who participated in this study, women entrepreneurs in Malaysia should have a proper business plan, a distinct business format, sufficient business information, business flexibility that is able to fit in any situation, having good access to ICT, able to focus on cost competitiveness to compete with rivals, financial stability, a good business operation management and wide business networking with various parties that may directly or indirectly influence their business operation (Cabrera \& Mauricio, 2017; Huck \& McEwen, 1991). Once the women entrepreneurs decide to expand their business to international level, they should be more concerned with improving their marketing strategies to enable their business to fit in well in the global arena.

Despite having a sufficient strength of organizational and individual factors, women entrepreneurs should also realize the importance of the environmental factors that they may not be able to control fully. Among the factors that exist in the international business environment that may affect a women entrepreneur's business success are cultural differences between home and host countries, the economic situation of both domestic and international countries and the legal procedures. Even though these factors could influence their business to a certain extent, women entrepreneurs may reduce their impacts by implementing a proactive strategy and anticipating the outcomes of each factor while doing a preliminary study before venturing into the foreign markets. 
Women entrepreneurs should also realize that there are many other environmental factors that may appear from time to time once they embarked on an international business. Precautionary steps should be prepared during the decision-making process of entering any new international market.

Regardless of how ready a women entrepreneur with the three main factors namely individual, organizational and environmental factors, their international business success may face some particular problems if they are not equipped with a suitable decision-making strategy, controlling strategy and leadership styles. These three factors may act as the mediating factors in the success of the internationalization process. A good decision maker will use various strategies that suit the current business context. In addition, only a genuine risk-taker can sense the best way out of a problem and able to realize and grab the new potential opportunities.

According to most of the participants, their spouse and family members provide support for their business expansion, i.e. moral and advice. However, there are also women entrep reneurs who mentioned they did not receive any support from both parties. Thus, they only believe in themselves and never look for any specific support from others. This shows that women can be successful without men's assistance if she firmly believes in herself and in her passion for doing the business right. In other words, men can just moderate the success of a women entrepreneur and not act as an essential determinant of their success.

\section{CONCLUSIONS}

This paper has identified some major issues and problems among women entrepreneurs in the context of international market. It has clearly contributed some significant findings and insights on developmental issues on women entrepreneurship. It is widely identified issue that women have different strengths, characteristics and weaknesses compared to men. Thus, Malaysian women entrepreneurs need to have a critical understanding of the entrepreneurial orientation for them to succeed in their ventures regardless of size and location. These orientations include confidence, persistence, strong willpower, risk-taking, creativity and innovativeness can be embedded within the women entrepreneurs through short courses, training programs, mentoring or even long-term courses. It would be helpful to capture quantitative perspective to find the most trend of women entrepreneurs in international market. Since this research focus on northern region of Malaysia, further research should explore the different region women entrepreneurs and their international business strategies.

\section{Corresponding Author}

Dr. Filzah Md Isa, Associate Professor, Taylors University, Lakeside Campus, Jalan Taylor's, 47500 Subang Jaya, Selangor Malaysia.

Email: Filzah.Mdlsa@taylors.edu.my

\section{REFERENCES}

Alam, S. S., Senik, Z. C., \& Jani, F. M. (2012). An Exploratory Study of Women Entrepreneurs in Malaysia: Motivation and Problems. Journal of Management Research, 4(4). https://doi.org/10.5296/jmr.v4i4.2377

Ali, J., Zakaria, N., Jaganathan, M., Rashid, N. A. M., Yacob, P., \& Gorondutse, A. H. (2017). 
Determinants of entrepreneurial intention: Empirical insights from Malaysian undergraduate business students. International Journal of Economic Research, 14(19).

Ariffin, A. S., Mohamed, S., Baqutayan, S., \& Mahdzir, A. M. (2017). Enhancing Women Entrepreneurship Development Framework : Policy \& Institution Gap and Challenges in the Case of Malaysia. Journal Of Science, Technology And Innovation Policy, 3(2), 1-12.

Babulal, V. (2017). Women own 1 in 5 companies in Malaysia: Statistics Dept. New Straits Times. Retrieved from https://www.nst.com.my/news/nation/2017/06/251038/women-own-1-5companies-malaysia-statistics-dept

Basha, A. M. M., Pranav, K. S., Rao, R. V. S. S. N., Madhavi, K., \& Sudha, P. S. (2013). A Study on the Development of Women Entrepreneurship in Nellore, AP, India. Research Journal of Management Sciences, 2(10), 1-5.

Cabrera, E. M., \& Mauricio, D. (2017). Factors affecting the success of women's entrepreneurship: a review of literature. International Journal of Gender and Entrepreneurship. https://doi.org/10.1108/IJGE-01-2016-0001

Carlos M. Gutierrez, J. (2017). Women Entrepreneurs Are Driving Economic Growth. Retrieved February 14, 2018, from https://www.huffingtonpost.com/entry/women-entrepreneurs-aredriving-economic-growth_us_59f7c3dce4b04494283378f3

Cooper, A. C., Gimeno-Gascon, F. J., \& Woo, C. Y. (1994). Initial human and financial capital as predictors of new venture performance. Journal of Business Venturing. https://doi.org/10.1016/0883-9026(94)90013-2

Dhillon, M. (2017). Challenges faced by Women Entrepreneur in India. Shiv Shakti International Journal in Multidisciplinary and Academic Research (SSIJMAR). https://doi.org/10.2139/ssrn.1650583

Ekpe, I., Razak, R. C., \& Mat, N. B. (2013). The Performance of Female Entrepreneurs : Credit , Training and the Moderating Effect of Attitude towards. International Journal of Management.

Hassan, F., Ramli, A., \& Mat Desa, N. (2014). Rural Women Entrepreneurs in Malaysia: What Drives Their Success? International Journal of Business and Management. https://doi.org/10.5539/ijbm.v9n4p10

Hodges, N., Watchravesringkan, K., Yurchisin, J., Karpova, E., Marcketti, S., Hegland, J., ... Childs, M. (2015). Women and apparel entrepreneurship: An exploration of small business challenges and strategies in three countries. International Journal of Gender and Entrepreneurship. https://doi.org/10.1108/IJGE-07-2014-0021

Huck, J. F., \& McEwen, T. (1991). Competencies Needed for Small Business Success: Perceptions. Journal of Small Business Management. https://doi.org/10.1016/j.athoracsur.2013.02.032

Ilhaamie, A. G. A. (2014). Challenges of Muslim Women Entrepreneurs in Malaysian SMEs. International Journal of Innovation, Management and Technology. https://doi.org/10.7763/IJIMT.2014.V5.553

Kian, T. P., Mi, C. X., \& Chun, C. C. E. (2016). An Exploratory study on the factors that influence the declination of women entrepreneurship. International Business Management.

Mahmood, R., \& Hanafi, N. (2013). Entrepreneurial Orientation and Business Performance of Women-Owned Small and Medium Enterprises in Malaysia: Competitive Advantage as a Mediator. International Journal of Business and Social Science. 
INTERNATIONAL JOURNAL OF ACADEMIC RESEARCH IN BUSINESS AND SOCIAL SCIENCES

Vol. 8, No. 12, Dec, 2018, E-ISSN: 2222-6990 @ 2018 HRMARS

https://doi.org/10.1177/0266242612455034

Marlow, S., \& Mcadam, M. (2013). Gender and entrepreneurship: advancing debate and challenging myths; exploring the mystery of the underperforming female entrepreneur. International Journal of Entrepreneurial Behaviour \& Research, 19(5), 8-24. https://doi.org/10.1108/13552551311299288

Mohd. Nordin, N. A., Abdul Hamid, A. H., Chong, C. W., Azmin, N., Nordin, M., Woon, C. C., \& Norizaton Azmin Mohd. Nordin, A. H. A. H. \& C. C. W. (2011). Factors affecting profitability of women entrepreneurs business in Malaysia. In Annual Summit on Business and Entrepreneurial Studies (ASBES 2011) Proceeding.

Mordi, C., Simpson, R., Singh, S., \& Okafor, C. (2010). The role of cultural values in understanding the challenges faced by female entrepreneurs in Nigeria. Gender in Management: An International Journal, 25(1), 5-21. https://doi.org/10.1108/17542411011019904

Mordi, C., Simpson, R., Singh, S., \& Okafor, C. (2010). The role of cultural values in understanding the challenges faced by female entrepreneurs in Nigeria. Gender in Management: An International Journal. https://doi.org/10.1108/17542411011019904

Orser, B. J., Elliott, C., \& Leck, J. (2011). Feminist attributes and entrepreneurial identity. Gender in Management: An International Journal, 26(8), 561-589. https://doi.org/10.1108/17542411111183884

Pandey, V. (2013). Factors Influencing Entrepreneurial Motivation of Women Entrepreneur. BVIMSR'S Journal of Management Research, 5(2), 101-08. Retrieved from http://www.bvimsr.com/documents/publication/2013V5N2/01.pdf

Rozita, A. M., Rozita, A., Nur Syakiran Akmal, I., \& Zalinah, A. (2015). Women and Entrepreneurship: An Overview of Women Entrepreneurship Programs in Malaysia. Special Issue on Social Entrepreneurship, 11(January), 15-28.

SMEs are backbone of the economy. (n.d.). Retrieved February 10, 2018, from http://www.smecorp.gov.my/index.php/en/policies/2015-12-21-09-09-49/sme-statistics

Wang, Q. (2018). Gender, race/ethnicity, and entrepreneurship: women entrepreneurs in a US south city. International Journal of Entrepreneurial Behavior \& Research, IJEBR-05-2017-0156. https://doi.org/10.1108/IJEBR-05-2017-0156

Watson, J. (2001). Examining the impact on performance of demographic differences between male and female controlled SMEs. Small Enterprise Research, 9(2), 55-70. https://doi.org/10.5172/ser.9.2.55

Yassin, A., Ali, S., Abdel, D., \& Ali, H. (2014). Entrepreneurial Orientation and Performance Of Women Owned And Managed Micro And Small Enterprises In Somalia. ZENITH International Journal of Multidisciplinary Research. https://doi.org/10.13140/RG.2.1.1563.6240

Yin, R. K. (2002). Applications of case study research. Applied Social Research Methods series. https://doi.org/10.1097/FCH.0b013e31822dda9e 